\title{
Adjuvant Vitamin C in critically ill patients undergoing renal replacement therapy: What's the right dose?
}

\author{
Paul E Marik ${ }^{*}$ and Michael $\mathrm{H}$ Hooper
}

Keywords: Vitamin C, Pharmacokinetics, Dialysis, Continuous renal replacement therapy

Recently there has been increased interest in the use of intravenous vitamin $\mathrm{C}$ as adjuvant therapy in patients with sepsis, acute respiratory distress syndrome (ARDS), burns and after cardiac arrest. The optimal dosage strategy in these patients is unclear with dosages varying from $50 \mathrm{mg} / \mathrm{kg} /$ day to $1584 \mathrm{mg} / \mathrm{kg} /$ day having being studied. The pharmacokinetics of intravenous vitamin $\mathrm{C}$ has been studied in healthy volunteers and critically ill patients. In healthy volunteers the pharmacokinetics of intravenous vitamin $\mathrm{C}$ are best described by a two-compartment linear dose-response relationship with a $1.25 \mathrm{~g}$ dose producing a peak concentration of approximately 885 umol/l [1]. De Grooth et al. studied the pharmacokinetics of a twice daily bolus of $1 \mathrm{~g}$ of vitamin $\mathrm{C}$ in critically ill septic patients [2]. The mean peak serum vitamin C concentration was $180 \mathrm{umol} / \mathrm{l}$ with a trough concentration of between 60 and $80 \mathrm{umol} / \mathrm{l}$; approximately $50 \%$ of the administered dose was renally excreted. Vitamin $\mathrm{C}$ is freely filtered in the glomerulus with renal losses increasing with increasing plasma concentrations. As a large proportion of the vitamin $C$ dose is renally excreted, serum levels will be significantly higher in anuric patients. Vitamin $\mathrm{C}$ is removed by renal replacement therapy [3-5]. The serum levels of vitamin $C$ in patients with acute kidney injury (AKI) receiving adjuvant intravenous vitamin $C$ and who are being treated with continuous renal replacement therapy (CRRT) has not been evaluated. Recently, Honore and colleagues proposed that patients (post cardiac arrest) not being treated with CRRT receive $6 \mathrm{~g}$ vitamin $\mathrm{C}$ daily and that the dose should be increased to $12 \mathrm{~g} /$ day in those receiving CRRT [6]. While we strongly agree that $6 \mathrm{~g} /$ day is likely the optimal dose of intravenous vitamin $\mathrm{C}$ in critically ill patients, [7] there is no data to suggest that the dose should be increased in patients receiving CRRT. Assuming a plasma vitamin C concentration of 200 umol/l with a hemofiltration dose $(\mathrm{CVVH})$ of $2 \mathrm{~L} / \mathrm{h}$ and a sieving coefficient of 1 , the patient would lose $1.68 \mathrm{~g} /$ day $(200 * 2 * 24=9600 \mathrm{umol} /$ day). A daily dose of $6 \mathrm{~g}$ /day should adequately cover this loss. As part of an IRB approved study investigating the accuracy of point-of-care glucose monitors (Accu-Chek, Roche, Indianapolis, IN) in septic patients $(n=72)$ receiving intravenous vitamin $C$ (6 g daily), we measured steady state trough and peak (within $30 \mathrm{~min}$ of end of infusion) vitamin $\mathrm{C}$ levels in 12 patients (Table 1) [8]. While the sample size is small, our limited data does not suggest dosage adjustment is required in patents receiving renal replacement therapy. Additional studies are required to confirm our findings.

Table 1 Vitamin C trough and peak levels stratified by renal funcion

\begin{tabular}{llll}
\hline & $\begin{array}{l}\text { S-creatinine } \\
(\mathrm{mg} / \mathrm{dl})\end{array}$ & $\begin{array}{l}\text { Vitamin C-trough } \\
(\mathrm{umol} / \mathrm{l})\end{array}$ & $\begin{array}{l}\text { Vitamin C- peak } \\
(\text { umol/l) }\end{array}$ \\
\hline No AKI $(n=5)$ & $0.56 \pm 0.25$ & $224 \pm 121$ & $543 \pm 276$ \\
$\mathrm{AKI}+\mathrm{CRRT}(n=4)$ & $1.3 \pm 1.1$ & $263 \pm 129$ & $461 \pm 194$ \\
$\begin{array}{l}\text { CRF + Intermittent HD } \\
(n=3)\end{array}$ & $4.6 \pm 3.1$ & $346 \pm 126$ & $914 \pm 205$ \\
\hline
\end{tabular}

$A K I$ acute kidney injury, CRRT continuous renal replacement therapy, CRF chronic renal failure, $H D$ hemodialysis

* Correspondence: marikpe@evms.edu

Division of Pulmonary and Critical Care Medicine, Eastern Virginia Medical

School, 825 Fairfax Av, Suite 410, Norfolk, VA 23507, United States of America

(c) The Author(s). 2018 Open Access This article is distributed under the terms of the Creative Commons Attribution 4.0 International License (http://creativecommons.org/licenses/by/4.0/), which permits unrestricted use, distribution, and

reproduction in any medium, provided you give appropriate credit to the original author(s) and the source, provide a link to the Creative Commons license, and indicate if changes were made. The Creative Commons Public Domain Dedication waiver (http://creativecommons.org/publicdomain/zero/1.0/) applies to the data made available in this article, unless otherwise stated. 


\section{Availability of data and materials}

Available on request.

\section{Authors' contributions}

PEM drafted the original version of the manuscript. MHH reviewed and revised the manuscript. Both authors have reviewed the final version of the manuscript and approve the manuscript for publication.

\section{Ethics approval and consent to participate}

Not applicable.

\section{Competing interests}

The authors declare that they have no competing interests.

\section{Publisher's Note}

Springer Nature remains neutral with regard to jurisdictional claims in published maps and institutional affiliations.

Received: 28 August 2018 Accepted: 12 September 2018

\section{Published online: 22 November 2018}

\section{References}

1. Padayatty SJ, Sun H, Wang Y, et al. Vitamin C pharmacokinetics: implications for oral and intravenous use. Ann Intern Med. 2004;140:533-7.

2. de Grooth HJ, Manubulu-Choo WP, Zandvliet A, et al. Vitamin C pharmacokinetics in critically ill patients: a randomized trial of four intravenous regimens. Chest. 2018;153:1368-77.

3. Morena M, Cristol JP, BosC JY, et al. Convective and diffusive losses of vitamin C during haemodiafiltration session: a contributive factor to oxidative stress in haemodialysis patients. Nephrol Dial Transplant. 2002;17:422-7.

4. Fehrman-Ekholm I, Lotsander A, Logan K, et al. Concentrations of vitamin C, vitamin B12 and folic acid in patients treated with hemodialysis and on-line hemodiafiltration or hemofiltration. Scand J Urol Nephrol. 2008:42:74-80.

5. Story DA, Ronco C, Bellomo R. Trace element and vitamin concentrations and losses in critically ill patients treated with continuous venovenous hemofiltration. Crit Care Med. 1999;27:220-3.

6. Honore PM, De Bels D, Preswau T, et al. Adjuvant vitamin C in cardiac arrest patients undergoing renal replacement therapy: an appeal for a higherdose. Crit Care. 2018;22:207.

7. Marik PE, Khangoora V, Rivera R, et al. Hydrocortisone, Vitamin C and Thiamine for the treatment of severe sepsis and septic shock: A retrospective before-after study. Chest. 2017;151:1229-38.

8. Stephenson E, Hooper MH, Marik PE. Vitamin C and Point of Care glucose measurements: A retrospective, Observational study. Chest. 2018; (in press). 